\title{
MIOKARDO INFARKTO, NESANT VAINIKINIŲ ARTERIJŲ OBSTRUKCIJOS (MINOVA), DIAGNOSTIKOS IR GYDYMO YPATUMAI
}

\author{
Audrẻ Alonderytė ${ }^{1}$, Pranas Šerpytis ${ }^{1,2,3,4}$, Rokas Šerpytis ${ }^{2,3}$, Joseph S. Alpert ${ }^{5}$, Qin M. Chen ${ }^{6}$ \\ ${ }^{I}$ Vilniaus universiteto Medicinos fakultetas, ${ }^{2}$ Vilniaus universiteto Medicinos fakulteto \\ Klinikinès medicinos institutas, ${ }^{3}$ Vilniaus universiteto ligoninès Santaros kliniku \\ Širdies ir kraujagysliu ligu klinika, ${ }^{4,3}$ Vilniaus universiteto ligoninès Santaros kliniku \\ Skubios medicinos centras, ${ }^{5}$ Department of Medicine, University of Arizona, \\ Medical School Tucson, ${ }^{6}$ University of Arizona Health Sciences, College of Medicine Tucson
}

Raktažodžiai: miokardo infarktas, koronarinè širdies liga, ūmus koronarinis sindromas, miokardo infarkto diagnostika, miokardo infarkto gydymas, koronarinių arterijų obstrukcija.

\begin{abstract}
Santrauka
Pirmasis miokardo infarktas aprašytas kone prieš 80 metų, tačiau miokardo infarktas, nesant vainikinių arterijų obstrukcijos (toliau - MINOVA), nustatytas dar neseniai. MINOVA pasireiškia 6-8 proc. pacientų, kuriems diagnozuotas ūmus miokardo infarktas (toliau - ŪMI). Šią pacientų grupę dažniau sudaro moterys (vidutiniškai apie 55 metų), tačiau, lyginant su ŪMI, šioje grupeje rečiau nustatoma hiperlipidemija. MINOVA pacientai reikalingi ypatingo dèmesio dèl skirtingų patofiziologinių reakcijų, kurios lemia skirtingą gydymą ir prognozę. Pagrindinès MINOVA sukeliančios priežastys yra vainikinių arterijų spazmas, vainikinių kraujagyslių aterominès plokštelès plyšimas ar erozija, mikrovaskulinè vainikinių arterijų disfunkcija, vainikinès kraujagyslès embolija (trombozè) bei spontaninè vainikinès arterijos disekacija. Pagrindinis tyrimas, padedantis atmesti kitas priežastis, imituojančias ŪMI, yra širdies magnetinis rezonansas. Šiai pacientų grupei tikslinga atlikti acetilcholino provokacinį mègini, optinès koherentinès tomografijos ar intravaskulinio ultragarso tyrimą bei hematologinị ištyrimą dèl trombofilijų. Klinikiniai tyrimai atskleide, jog šiems pacientams skiriami angiotenziną konvertuojančio fermento inhibitoriai bei statinai yra naudingi tolimesnei prognozei. Nenustačius obstrukcijos kraujagyslėse, t.y. ūmų susirgimą
\end{abstract}

sukèlusios priežasties, daugelis pacientų išrašomi i namus, nepaskiriant jokio arba paskiriant tik minimalų kardioprotekcinị medikamentinị gydymą.

\section{İvadas}

Klinikinèje praktikoje daugejja ŪMI patyrusių pacientu, kuriuos angiografiškai ištyrus, nerandama vainikinių arterijų obstrukcijos ( $<50$ proc. stenozė pagrindinèse epikardo kraujagyslèse). Miokardo infarktas, nesant vainikinių arterijų obstrukcijos, pasireiškia 6-8 proc. pacientų, kuriems diagnozuotas ŪMI, dažnesnis moterims, ypač - nesant ST segmento pakilimo [1]. Europos kardiologų draugijos 2018 m. paskelbtame „Ketvirtajame universaliame miokardo infarkto apibrěžimo" dokumente MINOVA aprašymui paskirtas atskiras skyrius [2]. MINOVA diagnozé, kaip ir ŪMI, parodo, jog miocitų pažaida atsirado dèl išeminio mechanizmo, todèl neišeminès priežastys, tokios kaip miokarditas, neįtraukiamos [1]. Diagnozės patvirtinimo kriterijai: atitinka ketvirtą universalų miokardo infarkto apibrèžimą, nestebima didesnè nei 50 proc. stenozė vainikinėse arterijose ir jokia kita priežastis nepaaiškina ūmaus pasireiškimo [3]. Galimi patofiziologiniai mechanizmai apima vainikinių kraujagyslių spazmą, mikrovaskulinę vainikinių kraujagyslių disfunkciją, aterosklerotinès plokštelès plyšimą ir eroziją, spontaninę vainikinių arterijų trombozę ar emboliją ir vainikinių kraujagyslių disekaciją [2,4]. Šiuo metu vienas iš pagrindinių diagnostinių tyrimų yra širdies ištyrimas magnetinio rezonanso metodu. Šio tyrimo pagalba pagrindinè MINOVA priežastis nustatoma 74 proc. pacientų [5]. Kiti papildomi tyrimai, tokie kaip provokaciniai mėginiai, intravaskuline sonografija, trombofilijos diagnostiniai tyrimai gali būti naudingi identifikuojant MINOVA sukeliančius mechaniz- 
mus [6]. Lyginant su ŪMI, MINOVA pacientai jaunesnio amžiaus, dažniau moterys, tačiau šiai pacientu grupei rečiau nustatoma hiperlipidemija, kai kiti kardiovaskulinės rizikos veiksniai išlieka panašūs. MINOVA gali būti sukelta ịvairių priežasčių, todèl norint parinkti tinkamą, efektyvų ir prognozę gerinantị gydymą, reikia specifinio paciento ištyrimo ir įvertinimo [7].

Tikslas - atlikti ne vèlesnių nei 10 metų mokslinių šaltinių, nagrinėjančių miokardo infarkto, nesant vainikinių arterijų obstrukcijos, sisteminę analizę, apibendrinti MINOVA diagnostikos ir gydymo ypatumus.

\section{Tyrimo objektas ir metodika}

Duomenys buvo renkami PubMed duomenų bazèje. Analizei naudoti visateksčiai straipsniai, kuomet jų pavadinimas, santrauka ar raktažodžiai atitiko apžvalgos tikslą. Analizuotos tik anglų kalba skelbtos publikacijos, pasirodžiusios ne vèliau nei prieš 10 metų. Analizei atrinktos ir išanalizuotos 34 publikacijos.

\section{Klinikinis tyrimas}

Miokardo infarkto, nesant obstrukcijos vainikinėse širdies kraujagyslèse, priežastys. Dažna MINOVA priežastis yra vainikinių arterijų spazmas (VAS). Net 46 proc. pacientu, kuriems atlikti provokaciniai testai, buvo nustatytas VAS [8]. Tai apibūdinama kaip stipri koronarinių kraujagyslių vazokonstrikcija ( $>90$ proc.), dèl kurios sutrinka miokardo kraujotaka [3]. VAS gali apimti lokalizuotą arterijos segmentą, tačiau kartais apima du ir daugiau tos pačios (daugiažidininis) ar kitos (daugiakraujagyslinis) arterijos segmentus [9]. Šiuos procesus gali sukelti atsakas i vaistus ar toksinus (pvz.: kokainas, fluoruracilas), kuris pasireiškia kraujagyslių lygiųjų raumenų hiperaktyvumu arba gali atsirasti spontaniškai dèl vainikinių arterijų tonuso sutrikimų [3]. Kita MINOVA priežastis - vainikinių arteriju aterominès plokštelès plyšimas ar erozija, nesant kraujagyslės obstrukcijos [8]. Plokštelès plyšimas gali paskatinti trombų formavimąsi, kuris sukelia ūmų koronarinị sindromą (ŪKS) dèl distalinès embolizacijos arba tam tikrais atvejais dèl laikinos trombozès su spontanine trombolize. Kitokiu patofiziologiniu mechanizmu pasižymi plokštelès erozija - ji atsiranda dèl endotelio ląstelių apoptozès, todèl endotelis praranda vientisumą. Patologinių tyrimų metu plokštelès erozija labiau asocijuota su vélyvesnès stadijos trombu (lyginant su plyšimu) ir dažnesne distaline embolizacija [3]. MINOVA gali sukelti ir mikrovaskulinè vainikinių arterijų disfunkcija (kartais dar vadinama širdies X sindromu), apibūdinama kaip praeinanti miokardo išemija su ST segmento pakitimais ir angina, nesant obstrukcijos vainikinèse arterijose ir epikardo spazmo [10,11]. Mikrovaskuliné disfunkcija gali būti išemijos priežastis arba miokardo pažeidimo pasekmè dèl išeminių ar kitų priežasčiu, tad norint išsiaiškinti mikrovaskulinès disfunkcijos vaidmeni, MINOVA pacientams reikia diferencijuoti šiuos mechanizmus, atliekant detalų paciento ištyrimą [3].

Jeigu įvyksta dalinė vainikinëje kraujagyslëje esančio trombo lizè, pasireiškianti neobstrukcine koronarine širdies liga (KŠL) angiografiškai su mikrocirkuliacija, įvyksta vainikinès kraujagyslès embolija (trombozè), kuri bus viena iš MINOVA priežasčių [3]. Vainikinių kraujagyslių trombozė gali ịvykti dẻl ịgimtų ar igytų krešèjimo sistemos sutrikimų, o embolija dèl koronarinio ar sisteminio arterinio trombo. Paveldima trombofilija atsiranda dèl Leideno V krešèjimo faktoriaus, $\mathrm{S}$ ir C baltymo nepakankamumo. Net 14 proc. MINOVA pacientų pasireiškia šie igimti sutrikimai. Igytas krešejjimo sutrikimas (antifosfolipidinis sindromas, mieloproliferacinès ligos) taip pat gali sukelti MINOVA. Esant prieširdžių virpéjimui, širdies vožtuvų ligoms, vegetacijoms ant vožtuvo, širdies navikui (pvz.: miksomai), embolijos tikimybe turètų būti aptariama kaip MINOVA priežastis [10].

Spontaninè koronarinès arterijos disekacija (SKAD) yra santykinai reta neaterosklerotinė ŪMI priežastis, dažniau pasireiškianti jaunoms moterims $(<50$ metų ). Nors SKAD dažnai sukelia dalini perfuzijos sutrikimą, tačiau kartais arterijos gali atrodyti normaliai ar beveik normaliai dèl laipsniško siaurejimo, todèl tai galètų būti dar viena galima MINOVA priežastis [3].

Miokardo infarkto, nesant obstrukcijos vainikinèse širdies kraujagyslėse, diagnostikos ypatumai. ŪKS diagnostikai pasitelkiamos detalios, ịrodymais pagrịstos gairès, ypatingas dèmesys skiriamas miokardo infarktui (MI) su ST ar be ST segmento pakilimo. MINOVA diagnostika nèra pakankamai išnagrinèta dèl įrodymais pagrịstos literatūros šaltinių bei klinikinių tyrimų nepakankamumo. Šiuo metu MI gydymo algoritmai siūlo atmesti galimas kitas priežastis, norint diagnozuoti MINOVA. Pradinis pacientų ịvertinimas įtariant ŪMI ir neobstrukcinę širdies ligą reikalingas kruopštaus klinikinio ištyrimo [3]. Svarbu ịvertinti priežastis, kurios galimai sukèlè miokardo pažaidą, vertintą kaip ịtariamas miokardo infarktas, nesant išemijos požymių [3]. Jeigu išlieka ūmaus miokardo infarkto klinikinè diagnozė, angiograma turètų būti dar kartą peržiūrima ir svarstomas kitų tyrimų, padedančių nustatyti ligą sukèlusią priežastị, paskyrimas [3]. Širdies magnetinis rezonansas laikomas pagrindiniu MINOVA tyrimu, nes juo galima ekskliuduoti miokarditą, Takotsubo sindromą ir kitas kardiomiopatijas. Norint išsiaiškinti MINOVA sukèlusias priežastis, reikia ištirti galimas patofiziologines priežastis [3]. Dèl plokštelès plyšimo ar erozijos atsiradęs trombas angiografiškai gali būti nematomas pagrindinèse epikardo kraujagyslèse, tačiau mio- 
nekrozė atsiranda dèl distalios embolizacijos. Optinès koherentinès tomografijos metu matomas kalcifikuotas mazgas su prastai apibrèžtais kontūrais, ịsikišančiais ị arterijos spindị [12]. Intravaskulinè sonografija geriau atspindi plokštelès plyšimą, nei eroziją. Pagal H. Reynolds ir kt. atliktą tyrimą, plokštelès plyšimas buvo nustatytas 38 proc. moterų, patyrusių MINOVA [13]. H. Ouldzein ir kt. studijos duomenimis, 68 MINOVA patyrusių pacientuc kohortoje 38 proc. tiriamujų nustatytas plokšstelès plyšimas [14]. Rezultatai galètų būti ir tikslesni, jei būtų naudotas geresnès rezoliucijos vaizdinis tyrimas, pvz., optinė koherentinè tomografija. Šiuo metodu galima nustatyti ne tik ịplyšimus, bet ir erozijas, galinčias sukelti MINOVA [15]. Plokštelès plyšimas buvo rastas toje vietoje, kur angiografiškai kraujagyslè beveik pusei pacientų atrodè normali, o visiems pacientams, kuriems angiografiškai buvo pastebèta net ir nedidelè aterosklerozè, rastas plokšstelès plyšimas [16]. Atsižvelgiant ị anamnezès duomenis, reikètų atkreipti dèmesị, kad plokštelès erozija labiau būdinga moterims, rūkantiems asmenims, esant vienos vainikinès arterijos ligai ir jaunesniems pacientams, turintiems kelis KŠL rizikos veiksnius [17]. Dažna MINOVA priežastis yra vainikinių arterijų spazmas, kai pacientai patiria krūtinès anginos priepuolius, susijusius su ST segmento pakilimu ramybejje, naktị ar anksti ryte. Kai EKG pokyčiai nedokumentuoti, diagnozė pagrindžiama acetilcholino provokaciniu testu, kur VAS apibrežiamas kaip bent 75 proc. kraujagysliu spindžio susiaurejjimas, esant miokardo infarkto simptomu [18]. Vienoje iš atliktų studijų VAS buvo diagnozuotas net 46 proc. MINOVA pacientu, atliekant provokacinius mèginius [19]. Šiuo metu MINOVA diagnostikai naudojama daug provokacinių mėginių, tačiau auksiniu standartu laikomas didelių dozių intrakoronarinis acetilcholino boliusų méginys (20-100 ug i intrakoronarinę $5 \mathrm{ml}$ dozę per $20 \mathrm{~s}$ ), o koronaru atsakas stebimas kontrastinès angiografijos metu [20] . I tyrimą ịtraukti pacientai, patyrę VAS ir mikrovaskulinę koronarų disfunkciją, tirti provokaciniu acetilcholino mėginiu, kuriems vèliau buvo atliekamas frakcinio širdies kraujagysliu tèkmès rezervo tyrimas (FFR), vainikinès tèkmès rezervo tyrimas (CFR) ir nustatomas mikrovaskulinio pasipriešinimo indeksas (IMR). Gauti rezultatai parodè, jog VAS, sumažejusi mikrovaskulinè vazodilatacija ir padidèjęs mikrovaskulinis rezistentiškumas (MR) gali pasireikšti ịvairiai. Nustatyta, jog MR padidèjimas (ribinè vertè 18.0) koreliuoja su pagrindinių nepageidaujamų kardiovaskulinių reiškinių atsiradimu, o VAS yra nepriklausomas padidejjusio MR (>18.0) rodiklis. Galima teigti, kad pacientų, turinčiu VAS ir padidejusį MR prognozè yra prastesnè, lyginant juos su kitais pacientais [21].

R. Montone ir kt. atliko su tyrimo saugumu susijusị tyrimą 80 MINOVA pacientų, kuriems buvo atliktas provo- kacinis tyrimas per 48 valandas nuo patekimo į ligoninę. Su procedūra susijusios aritmijos atsirado 5 proc. pacientų, pagrindinių nepageidaujamų reiškinių (tokių kaip mirtis ar pasikartojantis MI) nebuvo nustatyta [19]. I tariant, kad MINOVA priežastis gali būti koronaro trombozè ar embolizacija, reikètų atlikti kraujo krešejimo rodiklių tyrimus. Paveldimų koagulopatijų diagnostiniai mėginiai turètų būti atliekami pasikonsultavus su hematologu, pacientas turètuc būti ištirtas dèl Leideno faktoriaus, protrombino 20210A, VIII krešejimo faktoriaus, $\mathrm{C}$ ir $\mathrm{S}$ proteino, antitrombino, lupus antikoagulianto ir antifosfolipidinių antikūnų. Spontanine aortos disekacija galètų būti ịtariama $<50$ metų moterims, kurioms pasireiškè ūmus koronarinis sindromas ar ịvyko staigi kardialinè mirtis. Vainikinių arterijų angiografinè išvaizda gali kisti nuo beveik normalios vainikinès arterijos iki difuzinès stenozès, įskaitant ir $<50$ proc. stenozę. Spontaninei aortos disekacijai būdingas vienos vainikinès kraujagyslès vingiuotumas, įskaitant vadinamosios kamščiatraukio formos vaizdą, ir kelių kraujagyslių simetriškas vingiuotumas. Diagnozès patikslinimui reikalingi intravaskuliniai vaizdiniai tyrimai: intravaskuliné sonografija, optiné koherentinè tomografija, išryškinanti aterosklerozinę plokštelę, disekaciją ar intramuralinę hematomą. Šie tyrimai yra labai svarbūs ir informatyvūs dèl vaizdinès medžiagos rezoliucijos [3], tačiau reikètų atsargiau vertinti optinę koherentinę tomografiją dèl galimai kontrasto indukuotos hidraulinès disekacijos išsiplètimo [22].

Koronarų mikrovaskulinė disfunkcija gali būti nustatyta nuo 30 iki 50 proc. pacientų, jaučiančių krūtinès skausmus, tačiau angiografijoje matoma neobstrukcinè KŠL. Svarbu pabrèžti, kad esant MINOVA, skirtingai nuo neobstrukcinès KŠL, diagnozuojamas ịvykęs miokardo infarktas, tačiau tik 8 proc. moterų, sergančių stabilia mikrovaskuline liga, randas miokarde buvo rastas po širdies MRT (WISE studija), todèl kol kas negalima tiksliai atsakyti, ar MINOVA yra ŪMI priežastis, ar pasekmè [3].

Miokardo infarkto, nesant obstrukcijos vainikinėse širdies kraujagyslėse, gydymas. Nors MI su obstrukcine kraujagyslių liga gydymas yra gerai išnagrinètas, tačiau trūksta randomizuotų tyrimų apie MINOVA sergančių asmenų prevencinio gydymo veiksmingumą. E. Choo ir kt. tyrẻ MINOVA pacientų veiksnius, susijusius su mirtingumu, nepriklausomai nuo mirties priežasčių. Tyrime nustatyta, jog renino angiotenzino sistemos blokatorių ir statinų naudojimas susijęs su mažesniu MINOVA pacientų mirtingumu [23]. Panašūs duomenys gauti analizuojant 9138 MINOVA pacientus SWEDEHEART registre, kur vidutiniškai po 4,1 metu stebëjimo nustatytas ženkliai mažesnis mirtingumas dèl visų priežasčių, hospitalizacija dèl MI, insulto ir širdies nepakankamumo, kuris siejamas su statinų ir angiotenziną konver- 
tuojančio fermento inhibitorių preparatų vartojimu $[2,24]$.

Sąsaja su statinų vartojimu ir ligos baigtimi buvo pastebèta ne tik šiame, bet ir kituose randomizuotuose tyrimuose [25]. Pagrindinis mechanizmas, paaiškinantis statinu veiksmingumą, yra tas, kad jie stabilizuoja aterosklerotines plokšteles, todèl jos mažiau pažeidžiamos. Tai reiškia, kad ir nedidelių aterosklerotinių plokštelių plyšimas MINOVA pacientams gali sukelti miokardo infarktą. [26]. Be to, galimai vienas iš mechanizmų, lemiančiu geresnę MINOVA pacientų ligos baigtị, yra apsauginė kraujagyslių endotelio funkcija [27]. Atlikta nemažai studijų, irodančių renino-angiotenzino sistemos blokatorių naudą pacientams, sergantiems ne tik miokardo infarktu su širdies nepakankamumu ir sutrikusia kairiojo skilvelio funkcija, bet ir sergantiesiems KŠL, nesant širdies nepakankamumo ir sutrikusios kairiojo skilvelio funkcijos, kuriems gydymas AKFI turejjo teigiamą poveiki, vertinant mirštamumą ir mirtingumą [28, 29]. Šios grupès pacientams teigiamas AKFI poveikis galimai pasireiškia dèl kraujospūdị mažinančio poveikio, simpatinę sistemą inhibuojančio poveikio, paveikiantis endotelị ir skatinantis antifibrotinius procesus miokarde, kurie taip pat galimai svarbūs MINOVA pacientams ir gali paaiškinti teigiamą poveiki, gydant AKFI ir ARB [30-31]. Yra eksperimentinių tyrimų, irodžiusių, kad simpatinès autonominès nervų sistemos aktyvacija gali būti susijusi su kardiovaskuliniais ìvykiais, todèl po MI galètų būti tikslingas beta blokatorių naudojimas [30], tačiau SWEDEHEART atliktame tyrime beta blokatoriai neparodè ženklaus teigiamo poveikio, mažinant pagrindinius nepageidaujamus kardiovaskulinius reiškinius MINOVA pacietams [32]. Pagal esamas rekomendacijas, dviguba antitrombocitinè terapija yra rekomenduojama metus po ŪMI [33], nes mažina kardiovaskulinių reiškinių riziką [34]. SWEDEHART atliktas tyrimas parodè, jog MINOVA pacientams dviguba antitrombocitinè terapija nebuvo susijusi su mažesniu kardiovaskulinių ịvykių dažniu [32].

\section{Išvados}

1. Tarp sergančiujų MINOVA vyrauja moterys ir jaunesnio amžiaus asmenys, rečiau stebima dislipidemija.

2. MINOVA diagnozè nustatoma remiantis ketvirtuoju universaliu miokardo infarkto apibrèžimu, nesant obstrukcijos vainikinèse arterijos ( $<50$ proc. stenozė).

3. Vainikinių arterijų spazmas, vainikinių kraujagyslių aterominès plokštelès plyšimas ar erozija, mikrovaskulinè vainikinių arterijų disfunkcija, vainikinès kraujagyslès embolija (trombozè) bei spontaninè vainikinès arterijos disekacija laikomos pagrindinèmis MINOVA priežastimis.

4. Širdies magnetinio rezonanso tyrimas laikomas pagrindiniu diagnostiniu MINOVA tyrimu, padedančiu ekskliuduoti miokarditą, Takotsubo sindromą ir kitas kardiomiopatijas.
5. Angiotenziną konvertuojančio fermento inhibitoriai ir statinai mažina kardiovaskulinių reiškinių riziką MINOVA pacientams.

\section{Literatūra}

1. Thygesen K, Alpert JS, Jaffe AS, Chaitman BR, et al. Fourth universal definition of myocardial infarction (2018). European Heart Journal 2019;40(3):237-269.

https://doi.org/10.1093/eurheartj/ehy462

2. Alpert JS, Serpytis R, Serpytis P, Chen QM. Myocardial infarction with nonobstructive coronary arteries (MINOCA). Am J Med 2019;132(3):267-268.

https://doi.org/10.1016/j.amjmed.2018.12.005

3. Tamis-Holland JE, Jneid H, Reynolds HR, Agewall S, Brilakis ES, et al. Contemporary diagnosis and management of patients with myocardial infarction in the absence of obstructive coronary artery disease: a scientific statement from the American Heart Association. Circulation 2019;139(18):e891-e908.

https:/doi.org/10.1161/CIR.0000000000000670

4. Pasupathy S, Tavella R, Beltrame JF. myocardial infarction with nonobstructive coronary arteries (MINOCA): the past, present, and future management. Circulation 2017;135(16):1490-1493. https://doi.org/10.1161/CIRCULATIONAHA.117.027666

5. Dastidar AG, Baritussio A, De Garate E, Drobni Z, Biglino G, Singhal P, Milano EG, Angelini GD, Dorman S, Strange J, Johnson T, Bucciarelli-Ducci C. Prognostic role of CMR and conventional risk factors in myocardial infarction with nonobstructed coronary arteries. JACC Cardiovasc Imaging 2019;12(10):1973-1982.

https://doi.org/10.1016/j.jcmg.2018.12.023

6. Agewall S, Beltrame JF, Reynolds HR, Niessner A, Rosano G, Caforio AL, De Caterina R, Zimarino M, Roffi M, Kjeldsen K, Atar D, Kaski JC, Sechtem U, Tornvall P. Working group on cardiovascular pharmacotherapy. ESC working group position paper on myocardial infarction with non-obstructive coronary arteries. Eur Heart J 2017; 38:143-153.

https://doi.org/10.1093/eurheartj/ehw149

7. Pasupathy S, Air T, Dreyer RP, Tavella R, Beltrame JF. Systematic review of patients presenting with suspected myocardial infarction and nonobstructive coronary arteries. Circulation 2015;131(10):861-70.

https://doi.org/10.1161/CIRCULATIONAHA.114.011201

8. Bainey KR, Welsh RC, Alemayehu W, Westerhout CM, Traboulsi D, Anderson T, Brass N, Armstrong PW, Kaul P. Populationlevel incidence and outcomes of myocardial infarction with non-obstructive coronary arteries (MINOCA): insights from the Alberta contemporary acute coronary syndrome patients invasive treatment strategies (COAPT) study. Int J Cardiol 2018;264:12-17.

https://doi.org/10.1016/j.ijcard.2018.04.004

9. Lanza GA, Careri G, Crea F. Mechanisms of coronary artery spasm. Circulation 2011;124(16):1774-82. 
https://doi.org/10.1161/CIRCULATIONAHA.111.037283

10. Scalone G, Niccoli G \& Crea F. Editor's choice- pathophysiology, diagnosis and management of MINOCA: an update. European Heart Journal: Acute Cardiovascular Care, 2019;8(1):54-62. https://doi.org/10.1177/2048872618782414

11. Lanza GA, Crea F. Primary coronary microvascular dysfunction: clinical presentation, pathophysiology, and management. Circulation 2010;121(21):2317-25. https://doi.org/10.1161/CIRCULATIONAHA.109.900191

12. Dugan KE MA, Kwong RY, Mahajan AM, Reynolds HR. Calcified nodule as a cause of myocardial infarction with non-obstructive coronary artery disease. Int J Case Rep Images 2016;7:388-391.

https://doi.org/10.5348/ijcri-201670-CR-10658

13. Reynolds HR, Srichai MB, Iqbal SN, Slater JN, Mancini GB, Feit F, Pena-Sing I, Axel L, Attubato MJ, Yatskar L, Kalhorn RT, Wood DA, Lobach IV, Hochman JS. Mechanisms of myocardial infarction in women without angiographically obstructive coronary artery disease. Circulation 2011;124:1414-1425. https://doi.org/10.1161/CIRCULATIONAHA.111.026542

14. Ouldzein H, Elbaz M, Roncalli J, Cagnac R, Carrié D, Puel J, Alibelli-Chemarin MJ. Plaque rupture and morphological characteristics of the culprit lesion in acute coronary syndromes without significant angiographic lesion: analysis by intravascular ultrasound. Ann Cardiol Angeiol (Paris) 2012;61:20-26. https://doi.org/10.1016/j.ancard.2011.07.011

15. Kubo T, Imanishi T, Takarada S, Kuroi A, Ueno S, Yamano T, Tanimoto T, Matsuo Y, Masho T, Kitabata H, Tsuda K, Tomobuchi Y, Akasaka T. Assessment of culprit lesion morphology in acute myocardial infarction: ability of optical coherence tomography compared with intravascular ultrasound and coronary angioscopy. J Am Coll Cardiol. 2007;50:933-939. https://doi.org/10.1016/j.jacc.2007.04.082

16. Iqbal SN, Feit F, Mancini GB, Wood D, Patel R, Pena-Sing I, Attubato M, Yatskar L, Slater JN, Hochman JS, Reynolds HR. Characteristics of plaque disruption by intravascular ultrasound in women presenting with myocardial infarction without obstructive coronary artery disease. Am Heart J 2014; 167:715-722. https://doi.org/10.1016/j.ahj.2014.01.011

17. White SJ, Newby AC, Johnson TW. Endothelial erosion of plaques as a substrate for coronary thrombosis. Thromb Haemost 2016;115:509-519.

https://doi.org/10.1160/th15-09-0765

18. Niccoli G, Scalone G, Crea F. Acute myocardial infarction with no obstructive coronary atherosclerosis: mechanisms and management. Eur Heart J 2015;36(8):475-81.

https://doi.org/10.1093/eurheartj/ehu469

19. Montone RA, Niccoli G, Fracassi F, Russo M, Gurgoglione F, Cammà G, Lanza GA, Crea F. Patients with acute myocardial infarction and non-obstructive coronary arteries: safety and prognostic relevance of invasive coronary provocative tests. Eur Heart J 2018;39:91-98. https://doi.org/10.1093/eurheartj/ehx667

20. Beltrame JF, Crea F, Kaski JC, Ogawa H, Ong P, Sechtem U, Shimokawa H, Bairey Merz CN, on behalf of the coronary vasomotion disorders international study group (COVADIS). The who, what, why, when, how and where of vasospastic angina. Circ J 2016;80:289-298.

https://doi.org/10.1253/circj.CJ-15-1202

21. Suda A, Takahashi J, Hao K, et al. Coronary functional abnormalities in patients with angina and nonobstructive coronary artery disease. JACC J 2019;74(19): 2350-2360.

https://doi.org/10.1016/j.jacc.2019.08.1056

22. Hayes SN, Kim ESH, Saw J, Adlam D, Arslanian-Engoren C, et al. Spontaneous coronary artery dissection: current state of the science: a scientific statement from the American Heart Association. Circulation 2018;137:e523-e557.

https://doi.org/10.1161/CIR.0000000000000564

23. Choo EH, Chang K, Lee KY, Lee D, Kim JG, et al. Prognosis and predictors of mortality in patients suffering myocardial infarction with nonobstructive coronary arteries. J Am Heart Assoc 2019; 8(14):e011990.

https://doi.org/10.1161/JAHA.119.011990

24. Lindahl B, Baron T, Erlinge D, Hadziosmanovic N, Nordenskjold A, Gard A, Jernberg T. Medical therapy for secondary prevention and long-term outcome in patients with myocardial infarction with nonobstructive coronary artery disease. Circulation 2017;135:1481-1489.

https://doi.org/10.1161/CIRCULATIONAHA.116.026336

25. Collins R, Reith C, Emberson J, Armitage J, Baigent C, et al. Interpretation of the evidence for the efficacy and safety of statin therapy. Lancet 2016; 388(10059):2532-2561.

https://doi.org/10.1016/S0140-6736(16)31357-5

26. Ambrose JA, Tannenbaum MA, Alexopoulos D, HjemdahlMonsen CE, Leavy J, Weiss M, Borrico S, Gorlin R, Fuster $\mathrm{V}$. Angiographic progression of coronary artery disease and the development of myocardial infarction. J Am Coll Cardiol 1988;12:56-62.

https://doi.org/10.1016/0735-1097(88)90356-7

27. Calabrò P, Yeh ET. The pleiotropic effects of statins.Curr Opin Cardiol 2005;20:541-546.

https://doi.org/10.1097/01.hco.0000181482.99067.bf

28. Pfeffer MA, McMurray JJ, Velazquez EJ, Rouleau JL, Køber L, et al. Valsartan, captopril, or both in myocardial infarction complicated by heart failure, left ventricular dysfunction, or both. N Engl J Med 2003;349:1893-1906.

https://doi.org/10.1056/NEJMoa032292

29. Danchin N, Cucherat M, Thuillez C, Durand E, Kadri Z, Steg PG. Angiotensin-converting enzyme inhibitors in patients with coronary artery disease and absence of heart failure or left ventricular systolic dysfunction: an overview of long-term randomized controlled trials. Arch Intern Med 2006; 166:787-796. https://doi.org/10.1001/archinte.166.7.787

30. Grassi G, Seravalle G, Mancia G. Sympathetic activation in car- 
diovascular disease: evidence, clinical impact and therapeutic implications. Eur J Clin Invest. 2015;45:1367-1375.

https://doi.org/10.1111/eci.12553

31. Werner C, Baumhäkel M, Teo KK, Schmieder R, Mann J, Unger T, Yusuf S, Böhm M. RAS blockade with ARB and ACE inhibitors: current perspective on rationale and patient selection.Clin Res Cardiol 2008; 97:418-431.

https://doi.org/10.1007/s00392-008-0668-3

32. Mukherjee D. Myocardial infarction with nonobstructive coronary arteries: a call for individualized treatment. J Am Heart Assoc. 2019;8(14):e013361. https://doi.org/10.1161/JAHA.119.013361

33. Roffi M, Patrono C, Collet JP, Mueller C, Valgimigli M, et al. Management of acute coronary syndromes in patients presenting without persistent ST-segment elevation of the European Society of Cardiology. 2015 ESC Guidelines for the management of acute coronary syndromes in patients presenting without persistent ST-segment elevation: Task Force for the management of acute coronary syndromes in patients presenting without persistent ST-segment elevation of the European Society of Cardiology (ESC). Eur Heart J 2016;37:267-315. https://doi.org/10.1093/eurheartj/ehv320

34. Puymirat E, Riant E, Aissoui N, Soria A, Ducrocq G, et al. $\beta$ blockers and mortality after myocardial infarction in patients without heart failure: multicentre prospective cohort study. BMJ 2016; 354:i4801.

https://doi.org/10.1136/bmj.i4801

\section{MYOCARDIAL INFARCTION WITHOUT} CORONARY ARTERY OBSTRUCTION: PRINCIPLES OF DIAGNOSTICS AND TREATMENT

\section{A. Alonderytė, P. Šerpytis, R. Šerpytis, JS. Alpert, QM. Chen}

Keywords: myocardial infarction, coronary artery disease, acute coronary syndrome, myocardial infarction diagnostics, myocardial infarction treatment, coronary artery obstruction.
Summary

Even though the first myocardial infarction without significant coronary artery disease was described almost 80 years ago, the use of MINOCA (myocardial infarction with nonobstructive coronary arteries) term started relatively recently. MINOCA has been reported in $6-8 \%$ of patients diagnosed with acute myocardial infarction. It should be noted that this patient population is more likely to be female, patients tend to be younger and less likely to have hyperlipidemia. These patients require special attention because of the different pathophysiological mechanisms that lead to the different treatment and prognosis. The main causes of MINOCA are coronary artery spasm, coronary artery plaque rupture or erosion, microvascular coronary disfunction, coronary embolism (thrombosis) and spontaneous coronary artery dissection. The main investigation to rule out other causes that mimic acute myocardial infarction is cardiac magnetic resonance. It is also appropriate for this patient group to have an acetylcholine provocation test, optical coherence tomography or intravascular sonography and also hematologic examination for thrombophilia. Currently, clinical studies have shown that use of angiotensin converting enzyme inhibitors and statins in these patients is useful for further prognosis. Importantly, most of these patients are discharged home with minimal or even without cardioprotective therapies and without any reasonable explanation for this acute presentation.

Correspondence to: audre.alonderyte@gmail.com

Gauta 2020-02-20 